\title{
AIR QUALITY INDEX AS A TOOL FOR MONITORING ENVIRONMENTAL DEGRADATION AND HEALTH IMPLICATIONS
}

\author{
M. SANMI AWOPETU \& J. OLUGBENGA ARIBISALA \\ Department of Civil Engineering, Ekiti State University, Nigeria
}

\begin{abstract}
Considering the importance of air to human existence, air pollution is a critical issue that requires collective effort for its prevention and control. The anthropogenic activities keyed into a crystal responsibility which resulted in environmental dilapidation and ruin. One of the tools that can be used for such a campaign is Air Quality Index (AQI). This study carried out an air quality survey of some air pollutants in Ado-Ekiti, Ekiti State Nigeria with the view to develop the AQI. The AQI was based on the concentrations of four pollutants. The index is calculated from the concentrations of the following pollutants: $\mathrm{PM}_{2.5}, \mathrm{PM}_{10}, \mathrm{CO}$ and SO2. The air quality sample was taking in July 2017 (rainy season) and January 2018 (dry season) for a period of one week in each season. Seven sampling points across two environmental zones in the study area, namely commercial and residential (high-income and low-income areas), were considered, resulting in 42 samples for each of the 4 air pollutants, totaling 392 samples. The results show that the AQI was generally lower during the rainy season than the dry season, and that the AQI in the high-income residential areas was most favorable, ranging from good to unhealthy for sensitive group. The worst scenario was recorded in the commercial environmental zones, which ranged from moderate to hazardous. There is a need for constant and continuous monitoring of air quality for development of AQI, which in turn will enable clear communication of how clean or unhealthy the air in the study area is; it will usher in environmental degradation, dilapidation and will ruin the awareness campaign.
\end{abstract}

Keywords: air, quality, index, pollution, Ado Ekiti, environmental, degradation, pollutants.

\section{INTRODUCTION}

Air pollution can be described as a leading environmental problem associated with urban areas around the world. A range of monitoring programs have been put in place to determine the quality of air by generating huge amount of data on concentration of each air pollutant in different parts of the world. The large data often do not convey the air quality status to the scientific community, government officials, policy makers, and in particular to the general public in a simple and straightforward manner. This problem is addressed by determining the Air Quality Index (AQI) of a given area.

Human existence in comparison with its environment is more and more getting threatened sequel to air pollution occasioned majorly by human coupled with natural activities. Earth is getting warmer, the ozone layer is getting depleted, and acid rain is being experienced, all as a result of air pollution (Awopetu [1], Awopetu [2]). Nigeria is facing myriad of environmental issues which include but not limited to air pollution, improper waste disposal, water pollution, climate change and global warming that are of great concern to environmentalists (Awopetu [2]). The effects of this environmental degradation are detrimental to human, plant and animal existence. The anthropogenic activities keyed into a crystal responsibility which resulted in environmental dilapidation and ruin. In order for this trend to change there has to be environmental degradation, dilapidation and ruin campaign which will usher in awareness. One of the tools that can be used for such campaign is AQI. The AQI is a reporting system; an important tool of risk communication. 
Consciousness of everyday levels of air pollution is vital to the citizens, particularly for those who are suffering from illnesses occasioned by exposure to air pollution. Achievement of a nation to advance air quality is not unconnected with the cooperation and support of its citizens who are knowledgeable about local and national air pollution problems and about the progress of mitigation efforts (San Salvador [3]). Therefore, an uncomplicated and effective communication of air quality is very important. The theory of an AQI that transforms weighted values of individual air pollution related parameters such as Particulate matter $\left(\mathrm{PM}_{10}, \mathrm{PM}_{2.5}\right)$, Carbon monoxide $(\mathrm{CO})$ and Sulfur dioxide $\left(\mathrm{SO}_{2}\right)$ into a single number or set of numbers is widely used for air quality communication. In what follows is the explanation of individual pollutants that constituted the AQI

Carbon monoxide (CO) is a colorless, odorless gas created when a fuel is burned or from incomplete combustion of hydrocarbons in gasoline-powered engines such as generator, this is common especially in developing countries. It is practically impossible to detect the presence of $\mathrm{CO}$ through senses in an environment since $\mathrm{CO}$ has no smell or taste. It is worthy of note that there are reported cases of breathlessness, restlessness and unconsciousness following inhalation of fumes produced by an electric generator that was put in a confined area [4], [5]. As reported by (Aliyu and Ibrahim [6]) was a case of CO poisoning resulted in loss of consciousness as seen in a family of six children who slept in an overcrowded room, polluted with burning charcoal which was meant to generate heat for warmth.

According to Nordqvist [7]. Hemoglobin is the molecule in red blood cells that carries oxygen from the lungs to tissues all over the body, and it brings carbon dioxide $\left(\mathrm{CO}_{2}\right)$ back from the tissues. $\mathrm{CO}$ binds to hemoglobin over 200 times more easily than oxygen does, so if $\mathrm{CO}$ is present, oxygen will not be able to find space to get into the hemoglobin. This is because the space is occupied with $\mathrm{CO}$. As a result, parts of the body will be starved of oxygen, and the affected parts will die. The human body needs oxygen, but it has no use for $\mathrm{CO}$.

Sulfur dioxide $\left(\mathrm{SO}_{2}\right)$ belongs to the family of sulfur oxide (SOx) gases. These gases are formed when fuel containing sulfur (mainly coal, gasoline and fuel oil) is burned and during metal smelting and other industrial processes as well as in the oxidation of naturally occurring sulfur gases, as in volcanic eruptions. High concentrations of $\mathrm{SO}_{2}$ are associated with multiple health and environmental effects. Short-term exposure to airborne $\mathrm{SO}_{2}$ has been associated with various adverse health effects [8], [9]. Multiple human clinical studies, epidemiological studies, and toxicological studies support a causal relationship between short-term exposure to airborne $\mathrm{SO}_{2}$ and respiratory morbidity. Sulfur dioxide also causes acid rain which can damage or kill trees and crops.

$\mathrm{PM}_{10}$ is particulate matter 10 micrometers or less in diameter, $\mathrm{PM}_{2.5}$ is particulate matter 2.5 micrometers or less in diameter. $\mathrm{PM}_{2.5}$ is generally described as fine particles. The components of particulate matter (PM) include finely divided solids or liquids such as dust, fly ash, soot, smoke, aerosols, fumes, mists and condensing vapors that can be suspended in the air for extended periods of time. The smaller the particles, the deeper they can penetrate into the respiratory system and the more hazardous they are to breathe. The $\mathrm{PM}_{2.5}$ is more dangerous since they are so small and light, fine particles tend to stay longer in the air than heavier particles.

PM is also known to trigger or worsen chronic disease such as asthma, heart attack, bronchitis and other respiratory problems. Exposure to such particles can affect both lungs and heart. Numerous scientific studies have linked particle pollution exposure to a variety of problems, including; decreased lung function, increased respiratory symptoms, such as irritation of the airways, coughing or difficulty breathing. 
Several studies from across the world have documented the many ways in which air pollution can affect people's health, including but not limited to making it difficult to breathe for those with asthma or other respiratory diseases, regularly sending the young and old to hospital or causing them to miss school or work, and contributing to early death from heart and lung disease (Health Effects Institute [10]). Therefore, an AQI is helpful for: (i) public to know air quality in a simplified mode, (ii) politicians to know they cannot completely shield away from effects of air pollution and then invoke quick actions, (iii) a decision maker to be aware of the trend of air pollution events and to map out corrective pollution control strategies.

\section{MATERIAL AND METHODS}

\subsection{Study area}

Ado Ekiti is a city in southwest Nigeria, the state capital and headquarters of the Ekiti State. It is also known as Ado. It has a population of above 424, 340. The people of Ado Ekiti are mainly of the Ekiti sub-ethnic group of the Yorubas. Ado Ekiti has four tertiary educational institutions namely: Ekiti State University, Afe Babalola University and The Federal Polytechnic Ado Ekiti and Ekiti State School of Nursing and Midwifery. It also plays host to two local television and three radio stations; NTA Ado Ekiti, Ekiti State Television (ESBS), Ekiti FM, Voice FM and Progress FM Ado Ekiti. Various commercial banks and enterprises operate in Ado Ekiti. Ado Ekiti also have ninety-four (94) hotels and more than fifty (50) petrol stations all running on generating sets as source of electricity between two to twentyfour hours per day.

The town lies between the latitude $7^{0} 33^{1}$ and $7^{0} 42^{1}$ North of the equator and the longitude $5^{0} 11^{1}$ and $5^{0} 20^{1}$ East on a low land surrounded by several isolated hills and inselbergs, (Oyedele [11]). Geologically, the region lies entirely within the pre-Cambrian basement complex rock group, which underlies much of Ekiti State (Awosusi and Jegede [12]). The temperature of this area is almost uniform throughout the year; with little deviation from the mean annual temperature of $27^{\circ} \mathrm{C}$. February and March are the hottest $28^{\circ} \mathrm{C}$ and $29^{\circ} \mathrm{C}$ respectively, while June with temperature of $25^{\circ} \mathrm{C}$ is the coolest (Adebayo [13]). The mean annual rainfall is $1,367 \mathrm{~mm}$ with a low co-efficient variation of about $10 \%$ and 117 raining days in year 2017. Rainfall is highly seasonal with well-marked wet and dry season. The wet season lasts from April to October, with a break in August.

\subsection{Research method}

\subsubsection{Sampling}

Air sampling collection and analysis is required in order to quantify the air pollutants in the study area. To obtain valid data considering the fact that measuring air pollution is a complex task and requires due care and diligence, the following issues were put into consideration: (i) appropriateness of the sample points; (ii) how representative will the sample be in time and space; and (iii) how appropriate is the sampling equipment, analysis and calibration techniques.

Hand-held portable Aeroqual series 500 ambient air quality sampling equipment was used to measure $\mathrm{PM}_{2.5}, \mathrm{PM}_{10}, \mathrm{CO}$ and $\mathrm{SO}_{2}$. The air quality sample was taking in July 2017 (rainy season) and January 2018 (dry season) for a period of one week in each season. All sampling locations were sampled at different times of the day (morning, afternoon and evening). 
Morning readings were taken between $8 \mathrm{am}-11 \mathrm{am}$, afternoon readings between $12 \mathrm{pm}-3 \mathrm{pm}$ and evening readings were taken between $4 \mathrm{pm}-7 \mathrm{pm}$.

Seven sampling points across two environmental zones in the study area namely; commercial and residential (high income and low-income areas) were considered, resulting in 42 samples for each of the 4 air pollutant totaling 168 samples. Air monitoring was carried out in seven core sites which are as follows:

i) Old Garage: (this is characterized by retail shops, market, high vehicle and pedestrian traffic, it also serves as transfer point for minibuses and taxi linking other towns, urban, peri-urban and rural destinations);

ii) GRA: (represented high economic status residential area with low vehicular and pedestrian traffic volume);

iii) Ajilosun: (represented medium economic status residential area where majority of the residents either use kerosene or cooking gas for cooking);

iv) Dalimore Junction: (this serves as an important commuter route within ado Ekiti which represented heavy-traffic sites);

v) Odo Ado: Odo Ado-Ekiti (represent rural background area);

vi) Fajuyi Park: (represented civil engineering construction activity area); and

vii) Ilokun: (represented low economic status residential area where the houses are built of mud bricks without plastering and the floors were not paved or cemented. A lot of firewood burning activities were taking place).

The purpose of the AQI is to help people understand what local air quality means to their health. To make it easier to understand, USEPA has developed an AQI that is used to report air quality which is divided into six categories indicating increasing levels of health concern (Table 1). An AQI value over 300 represents hazardous air quality and below 50 the air quality is good, (US EPA, [14]).

Table 1: AQI. (Source: US EPA [14].)

\begin{tabular}{|c|c|c|}
\hline AQI Value & AQI Color & AQI Color \\
\hline $0-50$ & Good & Green \\
\hline $\mathbf{5 1 - 1 0 0}$ & Moderate & Yellow \\
\hline $101-150$ & Unhealthy for sensitive groups & Orange \\
\hline $151-200$ & Unhealthy & Red \\
\hline $201-300$ & Very unhealthy & Purple \\
\hline $301-500$ & Hazardous & Maroon \\
\hline
\end{tabular}

The AQI is a yardstick that runs from 0 to 500 . The higher the AQI value, the greater the level of air pollution and the greater the health concern. For example, an AQI value of 50 represents good air quality with little or no potential to affect public health, while an AQI value over 300 represents air quality so hazardous that everyone may experience serious effect (Table 2). 
Table 2: AQI health messages. (Source: US EPA [14].)

\begin{tabular}{|c|c|c|}
\hline AQI Value & Health Message & AQI Color \\
\hline $\mathbf{0 - 5 0}$ & None & Green \\
\hline $\mathbf{5 1 - 1 0 0}$ & $\begin{array}{c}\text { Unusually sensitive people should reduce prolonged } \\
\text { or heavy exertion }\end{array}$ & Yellow \\
\hline $\mathbf{1 0 1 - 1 5 0}$ & $\begin{array}{c}\text { Sensitive groups should reduce prolonged or heavy } \\
\text { exertion }\end{array}$ & Orange \\
\hline $\mathbf{1 5 1 - 2 0 0}$ & $\begin{array}{c}\text { Sensitive groups should avoid prolonged or heavy } \\
\text { exertion; general public should reduce prolonged or } \\
\text { heavy exertion }\end{array}$ & Purple \\
\hline $\mathbf{2 0 1 - 3 0 0}$ & $\begin{array}{c}\text { Sensitive groups should avoid all physical activity } \\
\text { outdoors; general public should avoid prolonged or } \\
\text { heavy exertion }\end{array}$ & Maroon \\
\hline $\mathbf{3 0 1 - 5 0 0}$ & Everyone should avoid all physical activity outdoors \\
\hline
\end{tabular}

\subsubsection{Computing the AQI}

Fourteen days (Monday to Sunday) monitors record concentrations of four pollutants at seven locations across the study area were taken. These raw measurements were converted into a separate AQI value for each day using standard equations (eqn (1)) developed by EPA. The $A Q I$ values are recorded as the AQI value for that day. The AQI is a piecewise linear function of the pollutant concentration. At the boundary between AQI categories (Table 3), there is a discontinuous jump of one AQI unit. To convert from concentration to AQI, eqn (1) is used [15].

$$
\mathrm{I}=\frac{\mathrm{I}_{\text {high }}-\mathrm{I}_{\text {low }}}{\mathrm{C}_{\text {high }}-\mathrm{C}_{\text {low }}}\left(\mathrm{C}-\mathrm{C}_{\text {low }}\right)+\mathrm{I}_{\text {low }},
$$

where $\mathrm{I}=\mathrm{AQI} ; \mathrm{C}=$ pollutant concentration; $\mathrm{C}_{\text {low }}=$ concentration breakpoint, that is $\leq \mathrm{C} ; \mathrm{C}_{\text {high }}$ $=$ concentration breakpoint that is $\geq \mathrm{C}$; $\mathrm{I}_{\text {low }}=$ index breakpoint corresponding to $\mathrm{C}_{\text {low }} ; \mathrm{I}_{\text {high }}=$ index breakpoint corresponding to $\mathrm{C}_{\text {high. }}$.

Table 3: Breakpoints for the AQI. (Source: US EPA [15].)

\begin{tabular}{|c|c|c|c|c|c|c|}
\hline $\mathrm{S} / \mathrm{N}$ & \multicolumn{4}{|c|}{ Breakpoints } & $\begin{array}{c}\text { Equal these } \\
\text { AQIs }\end{array}$ & Category \\
\hline 1 & $\begin{array}{c}\mathrm{PM}_{2.5} \\
\left(\mu \mathrm{g} / \mathrm{m}^{2}\right)\end{array}$ & $\begin{array}{c}\mathrm{PM}_{10} \\
\left(\mu \mathrm{g} / \mathrm{m}^{2}\right)\end{array}$ & $\mathrm{CO}(\mathrm{ppm})$ & $\mathrm{SO}_{2}(\mathrm{ppm})$ & AQI & \\
\hline 2 & $0.0-15.4$ & $0-54$ & $0.0-4.4$ & $0.000-0.034$ & $0-50$ & Good \\
\hline 3 & $15.5-40.4$ & $55-154$ & 4 & 0.03 & $51-100$ & Moderate \\
\hline 4 & $40.5-65.4$ & $155-254$ & 9 & 24 & 0 & $\begin{array}{l}\text { Unhealthy for } \\
\text { sensitive group }\end{array}$ \\
\hline 5 & $5.5-150.4$ & $255-354$ & 5.4 & 4 & $151-200$ & Unhealthy \\
\hline 6 & $150.5-250.4$ & $355-424$ & $15.5-30.4$ & $0.305-0.604$ & $201-300$ & Very unhealthy \\
\hline 7 & $250.5-350.4$ & $425-504$ & $30.5-40.4$ & 0.804 & $301-400$ & $\mathrm{Haz}$ \\
\hline 8 & $350.5-500.4$ & $505-604$ & $0.000-0.034$ & $0.805-1.004$ & $401-500$ & Hazardous \\
\hline
\end{tabular}




\section{RESULTS AND DISCUSSION}

It is seen from Tables 4 to 17 that the AQI ranges between good to hazardous during the raining season (Tables 4 to 10) and moderate to hazardous during the dry season (Tables 11 to 17). During the raining season, GRA (Table 5) had the best AQI which ranged between good and moderate while Old Garage (Table 4) had the worst AQI which ranged between moderate to hazardous. The friendly and acceptable AQI in GRA can be linked to the economic status of the people living in the area. GRA represents high economic status residential area with low vehicular and pedestrian traffic volume. The area also had a very low commercial activity with lots of green vegetations. Old Garage on the other hand is characterized with retail shops, market, high vehicle and pedestrian traffic; it also serves as transfer point for minibuses and taxi linking other towns, urban, peri-urban and rural destinations. It is the hub of commercial activities in the study area. Most of the retail shops in the Old Garage used generator for electricity supply. Woods, charcoal and kerosene stoves were used for cooking activities. All these anthropogenic activities are responsible for the worst AQI in the study area.

It was generally observed that AQI was worst in the dry season when compared with raining season, except Fajuyi (Table 9) which recorded hazardous in two days (Monday and Tuesday). GRA still recorded the friendliest AQI during the dry season, the AQI ranges between moderate to unhealthy for sensitive groups while Old Garage recorded the worst AQI (hazardous for seven days) during the same period. Hazardous levels of health concern, which are AQI values over 300, trigger health warnings of emergency conditions. The entire population is even more likely to be affected by serious health effects. Fajuyi (Table 16) also recorded hazardous on a Saturday while other days are mostly very unhealthy meaning everyone may experience more serious health effects.

Table 4: Daily AQI for Old Garage in Ado Ekiti during the raining season.

\begin{tabular}{|l|c|c|c|c|c|c|c|}
\hline $\begin{array}{l}\text { Day of the } \\
\text { week }\end{array}$ & $\begin{array}{c}\mathrm{PM}_{2.5} \\
\mu \mathrm{g} / \mathrm{m}^{3}\end{array}$ & $\begin{array}{c}\mathrm{PM}_{10} \\
\mu \mathrm{g} / \mathrm{m}^{3}\end{array}$ & $\begin{array}{c}\mathrm{CO} \\
\mathrm{ppm}\end{array}$ & $\begin{array}{c}\mathrm{SO}_{2} \\
\mathrm{ppm}\end{array}$ & AQI & Colors & Levels of health concerns \\
\hline Monday & 148 & 636 & 139 & 516 & 360 & & Hazardous \\
\hline Tuesday & 154 & 668 & 201 & 457 & 370 & & Hazardous \\
\hline Wednesday & 85 & 94 & 117 & 119 & 104 & & Unhealthy for sensitive group \\
\hline Thursday & 157 & 626 & 171 & 654 & 402 & & Hazardous \\
\hline Friday & 72 & 430 & 142 & 393 & 259 & & Unhealthy \\
\hline Saturday & 102 & 118 & 25 & 118 & 91 & & Moderate \\
\hline Sunday & 108 & 451 & 301 & 206 & 267 & & Unhealthy \\
\hline
\end{tabular}

Table 5: Daily AQI for GRA in Ado Ekiti during the raining season.

\begin{tabular}{|l|c|c|c|c|c|c|c|}
\hline $\begin{array}{l}\text { Day of the } \\
\text { week }\end{array}$ & $\begin{array}{c}\mathrm{PM}_{2.5} \\
\mu \mathrm{g} / \mathrm{m}^{3}\end{array}$ & $\begin{array}{c}\mathrm{PM}_{10} \\
\mu \mathrm{g} / \mathrm{m}^{3}\end{array}$ & $\begin{array}{c}\mathrm{CO} \\
\mathrm{ppm}\end{array}$ & $\begin{array}{c}\mathrm{SO}_{2} \\
\mathrm{ppm}\end{array}$ & AQI & Colors & Levels of health concerns \\
\hline Monday & 59 & 45 & 23 & 68 & 49 & & Good \\
\hline Tuesday & 57 & 46 & 9 & 68 & 45 & & Good \\
\hline Wednesday & 59 & 45 & 17 & 102 & 56 & & Moderate \\
\hline Thursday & 67 & 45 & 12 & 119 & 61 & & Moderate \\
\hline Friday & 66 & 57 & 20 & 119 & 65 & & Good \\
\hline Saturday & 61 & 54 & 12 & 65 & 48 & & Good \\
\hline Sunday & 54 & 49 & 18 & 10 & 33 & & \\
\hline
\end{tabular}


Table 6: Daily AQI for Ajilosun in Ado Ekiti during the raining season.

\begin{tabular}{|l|c|c|c|c|c|c|c|}
\hline $\begin{array}{l}\text { Day of the } \\
\text { week }\end{array}$ & $\begin{array}{c}\mathrm{PM}_{2.5} \\
\mu \mathrm{g} / \mathrm{m}^{3}\end{array}$ & $\begin{array}{c}\mathrm{PM}_{10} \\
\mu \mathrm{g} / \mathrm{m}^{3}\end{array}$ & $\begin{array}{c}\mathrm{CO} \\
\mathrm{ppm}\end{array}$ & $\begin{array}{c}\mathrm{SO}_{2} \\
\mathrm{ppm}\end{array}$ & AQI & Colors & Levels of health concerns \\
\hline Monday & 85 & 128 & 28 & 83 & 81 & & Moderate \\
\hline Tuesday & 87 & 125 & 37 & 65 & 78 & & Moderate \\
\hline Wednesday & 88 & 136 & 35 & 68 & 82 & & Moderate \\
\hline Thursday & 82 & 147 & 68 & 117 & 103 & & Unhealthy for sensitive group \\
\hline Friday & 73 & 133 & 65 & 179 & 112 & & Unhealthy for sensitive group \\
\hline Saturday & 73 & 94 & 77 & 189 & 109 & & Unhealthy for sensitive group \\
\hline Sunday & 63 & 60 & 65 & 54 & 61 & & Moderate \\
\hline
\end{tabular}

Table 7: Daily AQI for Dalimore in Ado Ekiti during the raining season.

\begin{tabular}{|l|c|c|c|c|c|c|c|}
\hline $\begin{array}{l}\text { Day of the } \\
\text { week }\end{array}$ & $\begin{array}{c}\mathrm{PM}_{2.5} \\
\mu \mathrm{g} / \mathrm{m}^{3}\end{array}$ & $\begin{array}{c}\mathrm{PM}_{10} \\
\mu \mathrm{g} / \mathrm{m}^{3}\end{array}$ & $\begin{array}{c}\mathrm{CO} \\
\mathrm{ppm}\end{array}$ & $\begin{array}{c}\mathrm{SO}_{2} \\
\mathrm{ppm}\end{array}$ & AQI & Colors & Levels of health concerns \\
\hline Monday & 122 & 118 & 90 & 29 & 72 & & Moderate \\
\hline Tuesday & 119 & 122 & 110 & 73 & 85 & & Moderate \\
\hline Wednesday & 112 & 117 & 111 & 123 & 92 & & Moderate \\
\hline Thursday & 117 & 110 & 144 & 135 & 101 & & Unhealthy for sensitive group \\
\hline Friday & 107 & 91 & 176 & 139 & 103 & & Unhealthy for sensitive group \\
\hline Saturday & 99 & 87 & 201 & 127 & 103 & & Unhealthy for sensitive group \\
\hline Sunday & 81 & 67 & 198 & 198 & 109 & & Unhealthy for sensitive group \\
\hline
\end{tabular}

Table 8: Daily AQI for Odo Ado in Ado Ekiti during the raining season.

\begin{tabular}{|l|c|c|c|c|c|c|c|}
\hline $\begin{array}{l}\text { Day of the } \\
\text { week }\end{array}$ & $\begin{array}{c}\mathrm{PM}_{2.5} \\
\mu \mathrm{g} / \mathrm{m}^{3}\end{array}$ & $\begin{array}{c}\mathrm{PM}_{10} \\
\mu \mathrm{g} / \mathrm{m}^{3}\end{array}$ & $\begin{array}{c}\mathrm{CO} \\
\mathrm{ppm}\end{array}$ & $\begin{array}{c}\mathrm{SO}_{2} \\
\mathrm{ppm}\end{array}$ & AQI & Colors & Levels of health concerns \\
\hline Monday & 81 & 87 & 121 & 101 & 97 & & Moderate \\
\hline Tuesday & 84 & 98 & 51 & 122 & 89 & & Moderate \\
\hline Wednesday & 124 & 160 & 78 & 82 & 111 & & Moderate \\
\hline Thursday & 157 & 193 & 87 & 74 & 128 & & Unhealthy for sensitive group \\
\hline Friday & 154 & 184 & 55 & 56 & 112 & & Moderate \\
\hline Saturday & 111 & 352 & 61 & 97 & 155 & & Unhealthy for sensitive group \\
\hline Sunday & 66 & 315 & 117 & 95 & 148 & & Unhealthy for sensitive group \\
\hline
\end{tabular}

Table 9: Daily AQI for Fajuyi in Ado Ekiti during the raining season.

\begin{tabular}{|l|c|c|c|c|c|c|c|}
\hline $\begin{array}{l}\text { Day of the } \\
\text { week }\end{array}$ & $\begin{array}{c}\mathrm{PM}_{2.5} \\
\mu \mathrm{g} / \mathrm{m}^{3}\end{array}$ & $\begin{array}{c}\mathrm{PM}_{10} \\
\mu \mathrm{g} / \mathrm{m}^{3}\end{array}$ & $\begin{array}{c}\mathrm{CO} \\
\mathrm{ppm}\end{array}$ & $\begin{array}{c}\mathrm{SO}_{2} \\
\mathrm{ppm}\end{array}$ & AQI & Colors & Levels of health concerns \\
\hline Monday & 190 & 979 & 79 & 29 & 319 & & Hazardous \\
\hline Tuesday & 191 & 979 & 98 & 73 & 335 & & Hazardous \\
\hline Wednesday & 171 & 523 & 109 & 123 & 231 & & Very unhealthy \\
\hline Thursday & 183 & 448 & 112 & 135 & 219 & & Very unhealthy \\
\hline Friday & 181 & 624 & 127 & 139 & 268 & & Very unhealthy \\
\hline Saturday & 173 & 457 & 122 & 127 & 220 & & Very unhealthy \\
\hline Sunday & 155 & 500 & 163 & 198 & 254 & & Very unhealthy \\
\hline
\end{tabular}


Table 10: Daily AQI for Ilokun in Ado Ekiti during the raining season.

\begin{tabular}{|l|c|c|c|c|c|c|c|}
\hline $\begin{array}{l}\text { Day of the } \\
\text { week }\end{array}$ & $\begin{array}{c}\mathrm{PM}_{2.5} \\
\mu \mathrm{g} / \mathrm{m}^{3}\end{array}$ & $\begin{array}{c}\mathrm{PM}_{10} \\
\mu \mathrm{g} / \mathrm{m}^{3}\end{array}$ & $\begin{array}{c}\mathrm{CO} \\
\mathrm{ppm}\end{array}$ & $\begin{array}{c}\mathrm{SO}_{2} \\
\mathrm{ppm}\end{array}$ & AQI & Colors & Levels of health concerns \\
\hline Monday & 67 & 61 & 3 & 300 & 108 & & Moderate \\
\hline Tuesday & 66 & 57 & 4 & 520 & 161 & & Unhealthy \\
\hline Wednesday & 64 & 56 & 1 & 505 & 156 & & Unhealthy \\
\hline Thursday & 69 & 58 & 1 & 473 & 150 & & Unhealthy for sensitive group \\
\hline Friday & 59 & 55 & 1 & 269 & 96 & & Moderate \\
\hline Saturday & 62 & 48 & 9 & 269 & 97 & & Moderate \\
\hline Sunday & 67 & 45 & 12 & 119 & 61 & & Moderate \\
\hline
\end{tabular}

Table 11: Daily AQI for Old Garage in Ado Ekiti during the dry season.

\begin{tabular}{|l|c|c|c|c|c|c|c|}
\hline $\begin{array}{l}\text { Day of the } \\
\text { week }\end{array}$ & $\begin{array}{c}\mathrm{PM}_{2.5} \\
\mu \mathrm{g} / \mathrm{m}^{3}\end{array}$ & $\begin{array}{c}\mathrm{PM}_{10} \\
\mu \mathrm{g} / \mathrm{m}^{3}\end{array}$ & $\begin{array}{c}\mathrm{CO} \\
\mathrm{ppm}\end{array}$ & $\begin{array}{c}\mathrm{SO}_{2} \\
\mathrm{ppm}\end{array}$ & AQI & Colors & Levels of health concerns \\
\hline Monday & 166 & 821 & 185 & 654 & 457 & & Hazardous \\
\hline Tuesday & 167 & 842 & 206 & 599 & 453 & & Hazardous \\
\hline Wednesday & 156 & 1032 & 154 & 511 & 463 & & Hazardous \\
\hline Thursday & 179 & 819 & 205 & 534 & 434 & & Hazardous \\
\hline Friday & 191 & 553 & 157 & 463 & 341 & & Hazardous \\
\hline Saturday & 158 & 640 & 83 & 656 & 384 & & Hazardous \\
\hline Sunday & 175 & 606 & 233 & 513 & 382 & & Hazardous \\
\hline
\end{tabular}

Table 12: Daily AQI for GRA in Ado Ekiti during the dry season.

\begin{tabular}{|l|c|c|c|c|c|c|c|}
\hline $\begin{array}{l}\text { Day of the } \\
\text { week }\end{array}$ & $\begin{array}{c}\mathrm{PM}_{2.5} \\
\mu \mathrm{g} / \mathrm{m}^{3}\end{array}$ & $\begin{array}{c}\mathrm{PM}_{10} \\
\mu \mathrm{g} / \mathrm{m}^{3}\end{array}$ & $\begin{array}{c}\mathrm{CO} \\
\mathrm{ppm}\end{array}$ & $\begin{array}{c}\mathrm{SO}_{2} \\
\mathrm{ppm}\end{array}$ & AQI & Colors & Levels of health concerns \\
\hline Monday & 63 & 52 & 55 & 237 & 102 & & Unhealthy for sensitive group \\
\hline Tuesday & 59 & 53 & 50 & 237 & 100 & & Moderate \\
\hline Wednesday & 63 & 56 & 54 & 248 & 105 & & Unhealthy for sensitive group \\
\hline Thursday & 58 & 56 & 49 & 355 & 129 & & Unhealthy for sensitive group \\
\hline Friday & 58 & 58 & 53 & 308 & 119 & & Unhealthy for sensitive group \\
\hline Saturday & 52 & 54 & 36 & 267 & 102 & & Unhealthy for sensitive group \\
\hline Sunday & 54 & 51 & 38 & 251 & 99 & & Moderate \\
\hline
\end{tabular}

Table 13: Daily AQI for Ajilosun in Ado Ekiti during the dry season.

\begin{tabular}{|l|c|c|c|c|c|c|c|}
\hline $\begin{array}{l}\text { Day of the } \\
\text { week }\end{array}$ & $\begin{array}{c}\mathrm{PM}_{2.5} \\
\mu \mathrm{g} / \mathrm{m}^{3}\end{array}$ & $\begin{array}{c}\mathrm{PM}_{10} \\
\mu \mathrm{g} / \mathrm{m}^{3}\end{array}$ & $\begin{array}{c}\mathrm{CO} \\
\mathrm{ppm}\end{array}$ & $\begin{array}{c}\mathrm{SO}_{2} \\
\mathrm{ppm}\end{array}$ & $\mathrm{AQI}$ & Colors & Levels of health concerns \\
\hline Monday & 106 & 375 & 57 & 45 & 146 & & Unhealthy for sensitive group \\
\hline Tuesday & 107 & 392 & 63 & 65 & 157 & & Unhealthy \\
\hline Wednesday & 77 & 178 & 124 & 82 & 115 & & Unhealthy for sensitive group \\
\hline Thursday & 105 & 386 & 150 & 21 & 165 & & Unhealthy \\
\hline Friday & 90 & 291 & 128 & 188 & 174 & & Unhealthy \\
\hline Saturday & 112 & 384 & 69 & 14 & 145 & & Unhealthy for sensitive group \\
\hline Sunday & 176 & 292 & 124 & 32 & 156 & & Unhealthy \\
\hline
\end{tabular}


Table 14: Daily AQI for Odo Ado in Ado Ekiti during the dry season.

\begin{tabular}{|l|c|c|c|c|c|c|c|}
\hline $\begin{array}{l}\text { Day of the } \\
\text { week }\end{array}$ & $\begin{array}{c}\mathrm{PM}_{2.5} \\
\mu \mathrm{g} / \mathrm{m}^{3}\end{array}$ & $\begin{array}{c}\mathrm{PM}_{10} \\
\mu \mathrm{g} / \mathrm{m}^{3}\end{array}$ & $\begin{array}{c}\mathrm{CO} \\
\mathrm{ppm}\end{array}$ & $\begin{array}{c}\mathrm{SO}_{2} \\
\mathrm{ppm}\end{array}$ & AQI & Colors & Levels of health concerns \\
\hline Monday & 66 & 84 & 172 & 453 & 194 & & Unhealthy \\
\hline Tuesday & 93 & 253 & 149 & 250 & 186 & & Unhealthy \\
\hline Wednesday & 83 & 200 & 146 & 578 & 252 & & Very unhealthy \\
\hline Thursday & 71 & 236 & 189 & 403 & 225 & & Very unhealthy \\
\hline Friday & 68 & 195 & 213 & 285 & 190 & & Unhealthy \\
\hline Saturday & 103 & 303 & 212 & 413 & 258 & & Very unhealthy \\
\hline Sunday & 115 & 92 & 145 & 386 & 185 & & Unhealthy \\
\hline
\end{tabular}

Table 15: Daily AQI for Dalimore in Ado Ekiti during the dry season.

\begin{tabular}{|l|c|c|c|c|c|c|c|}
\hline $\begin{array}{l}\text { Day of the } \\
\text { week }\end{array}$ & $\begin{array}{c}\mathrm{PM}_{2.5} \\
\mu \mathrm{g} / \mathrm{m}^{3}\end{array}$ & $\begin{array}{c}\mathrm{PM}_{10} \\
\mu \mathrm{g} / \mathrm{m}^{3}\end{array}$ & $\begin{array}{c}\mathrm{CO} \\
\mathrm{ppm}\end{array}$ & $\begin{array}{c}\mathrm{SO}_{2} \\
\mathrm{ppm}\end{array}$ & AQI & Colors & Levels of health concerns \\
\hline Monday & 137 & 140 & 154 & 385 & 204 & & Very unhealthy \\
\hline Tuesday & 143 & 136 & 148 & 350 & 194 & & Unhealthy \\
\hline Wednesday & 127 & 104 & 55 & 579 & 216 & & Very unhealthy \\
\hline Thursday & 148 & 171 & 179 & 398 & 224 & & Very unhealthy \\
\hline Friday & 142 & 209 & 93 & 373 & 204 & & Very unhealthy \\
\hline Saturday & 151 & 208 & 150 & 218 & 182 & & Unhealthy \\
\hline Sunday & 153 & 154 & 139 & 330 & 194 & & Unhealthy \\
\hline
\end{tabular}

Table 16: Daily AQI for Fajuyi in Ado Ekiti during the dry season.

\begin{tabular}{|l|c|c|c|c|c|c|c|}
\hline $\begin{array}{l}\text { Day of the } \\
\text { week }\end{array}$ & $\begin{array}{c}\mathrm{PM}_{2.5} \\
\mu \mathrm{g} / \mathrm{m}^{3}\end{array}$ & $\begin{array}{c}\mathrm{PM}_{10} \\
\mu \mathrm{g} / \mathrm{m}^{3}\end{array}$ & $\begin{array}{c}\mathrm{CO} \\
\mathrm{ppm}\end{array}$ & $\begin{array}{c}\mathrm{SO}_{2} \\
\mathrm{ppm}\end{array}$ & AQI & Colors & Levels of health concerns \\
\hline Monday & 138 & 621 & 79 & 283 & 280 & & Very unhealthy \\
\hline Tuesday & 137 & 354 & 112 & 67 & 167 & & Unhealthy \\
\hline Wednesday & 105 & 412 & 163 & 100 & 195 & & Unhealthy \\
\hline Thursday & 139 & 614 & 98 & 173 & 256 & & Very unhealthy \\
\hline Friday & 150 & 494 & 127 & 191 & 241 & & Very unhealthy \\
\hline Saturday & 140 & 780 & 207 & 88 & 304 & & Hazardous \\
\hline Sunday & 131 & 153 & 129 & 460 & 218 & & Very unhealthy \\
\hline
\end{tabular}

Table 17: Daily AQI for Ilokun in Ado Ekiti during the dry season.

\begin{tabular}{|l|c|c|c|c|c|c|c|}
\hline $\begin{array}{l}\text { Day of the } \\
\text { week }\end{array}$ & $\begin{array}{c}\mathrm{PM}_{2.5} \\
\mu \mathrm{g} / \mathrm{m}^{3}\end{array}$ & $\begin{array}{c}\mathrm{PM}_{10} \\
\mu \mathrm{g} / \mathrm{m}^{3}\end{array}$ & $\begin{array}{c}\mathrm{CO} \\
\mathrm{ppm}\end{array}$ & $\begin{array}{c}\mathrm{SO}_{2} \\
\mathrm{ppm}\end{array}$ & $\mathrm{AQI}$ & Colors & Levels of health concerns \\
\hline Monday & 80 & 62 & 6 & 563 & 178 & & Unhealthy \\
\hline Tuesday & 69 & 55 & 5 & 549 & 170 & & Unhealthy \\
\hline Wednesday & 73 & 46 & 8 & 355 & 121 & & Unhealthy for sensitive group \\
\hline Thursday & 81 & 54 & 16 & 642 & 198 & & Unhealthy \\
\hline Friday & 67 & 41 & 0 & 307 & 104 & & Unhealthy for sensitive group \\
\hline Saturday & 69 & 53 & 11 & 320 & 113 & & Unhealthy for sensitive group \\
\hline Sunday & 108 & 63 & 9 & 255 & 109 & & Unhealthy for sensitive group \\
\hline
\end{tabular}


Tables 18 and 19 shows the weekly AQI for the study area during raining and dry season respectively. The overall AQI index in GRA for both seasons still remains most favorable, followed by that of Ilokun while Old Garage and Fajuyi still recorded the worst AQI scenario.

Table 18: Weekly AQI for Ado Ekiti during the raining.

\begin{tabular}{|l|c|c|c|c|c|c|c|}
\hline Location & $\begin{array}{c}\mathrm{PM}_{2.5} \\
\mu \mathrm{g} / \mathrm{m}^{3}\end{array}$ & $\begin{array}{c}\mathrm{PM}_{10} \\
\mu \mathrm{g} / \mathrm{m}^{3}\end{array}$ & $\begin{array}{c}\mathrm{CO} \\
\mathrm{ppm}\end{array}$ & $\begin{array}{c}\mathrm{SO}_{2} \\
\mathrm{ppm}\end{array}$ & $\mathrm{AQI}$ & Colors & Levels of health concerns \\
\hline Old Garage & 118 & 432 & 157 & 352 & 265 & & Very unhealthy \\
\hline GRA & 60 & 48 & 16 & 79 & 51 & & Moderate \\
\hline Ajilosun & 79 & 118 & 54 & 108 & 89 & & Moderate \\
\hline Dalimore & 108 & 102 & 147 & 118 & 119 & & Unhealthy for sensitive group \\
\hline Odo Ado & 111 & 198 & 81 & 90 & 120 & & Unhealthy for sensitive group \\
\hline Fajuyi & 178 & 644 & 116 & 118 & 264 & & Very unhealthy \\
\hline Ilokun & 65 & 54 & 4 & 350 & 118 & & Unhealthy for sensitive group \\
\hline
\end{tabular}

Table 19: Weekly AQI for Ado Ekiti during the dry season.

\begin{tabular}{|l|c|c|c|c|c|c|c|}
\hline Location & $\begin{array}{c}\mathrm{PM}_{2.5} \\
\mu \mathrm{g} / \mathrm{m}^{3}\end{array}$ & $\begin{array}{c}\mathrm{PM}_{10} \\
\mu \mathrm{g} / \mathrm{m}^{3}\end{array}$ & $\begin{array}{c}\mathrm{CO} \\
\mathrm{ppm}\end{array}$ & $\begin{array}{c}\mathrm{SO}_{2} \\
\mathrm{ppm}\end{array}$ & $\mathrm{AQI}$ & Colors & Levels of health concerns \\
\hline Old Garage & 170 & 759 & 175 & 561 & 416 & & Hazardous \\
\hline GRA & 58 & 54 & 48 & 272 & 108 & & Unhealthy for sensitive group \\
\hline Ajilosun & 111 & 328 & 102 & 64 & 151 & & Unhealthy \\
\hline Dalimore & 86 & 195 & 175 & 396 & 213 & & Very unhealthy \\
\hline Odo Ado & 143 & 160 & 131 & 376 & 203 & & Very unhealthy \\
\hline Fajuyi & 134 & 490 & 131 & 194 & 237 & & Very unhealthy \\
\hline Ilokun & 78 & 53 & 8 & 427 & 142 & & Unhealthy for sensitive group \\
\hline
\end{tabular}

\section{CONCLUSIONS AND RECOMMENDATIONS}

This study presents the AQI for Ado Ekiti in Nigeria. As shown; the inhabitants of the study area are perpetually exposed to a diversity of pollutants as indicated by the measured AQI concentration. The main conclusion drawn is that, Ado Ekiti air is polluted and the level of human exposure to the pollutants requires further investigation to ascertain the health effect among the populace. The conclusion is supported by a number of epidemiological studies on the effects of air pollutants such as $\mathrm{PM}_{2.5}, \mathrm{PM}_{10}, \mathrm{CO}$, and $\mathrm{SO}_{2}$ on human health. It was discovered that most of the air pollutants sampled for the development of AQI was disgustingly higher than the World health organization (WHO) standard thereby posing great risk to the public health in particular and the environment in general. The federal, state and local government is doing nothing to mitigate the air pollutant in the study area. There is a need for continuous of air pollutants, regular development of AQI and public education on the adverse effects of air pollution on both health and environment. As it were, air pollution and its attendant consequences in the urban area under study should be made public. Steps that could be taken for air pollution mitigation at individual and domestic level should be clearly spelt out. Considering the AQI in most of the study locations, government intervention in terms of air quality regulation and mitigation is much needed. 


\section{REFERENCES}

[1] Awopetu M.S., Effect of air pollution on rain water: A case study of Ado-Ekiti, Nigeria. International Journal of Advanced Engineering Research and Science, 5(8), pp. 19-24, 2018.

[2] Awopetu, M.S., Effect of air pollution on dew water: A case study of Ado-Ekiti. Nigeria American Journal of Engineering Research, 7(8), pp. 88-93, 2018.

[3] US EPA, Air Quality Index (AQI) Air Quality Communication Workshop, San Salvador, El Salvador, 2012. www.epa.gov/sites/production/files/2014-05/documents/ zell-aqi.pdf Accessed on: 19 Aug. 2018.

[4] Afolayan, J.M., Edomwonyi, N.P. \& Esangbedo, S.E., Carbon monoxide poisoning in a Nigerian home: case reports. Nigerian Postgraduate Medical Journal, 21(2), pp. 199-202, 2014.

[5] Seleye-Fubara, D., Etebu, E.N. \& Athanasius, B., Pathology of deaths from carbon monoxide poisoning in Port Harcourt: an autopsy study of 75 cases. Nigerian Journal of Medicine, 20(3), pp. 337-340, 2011.

[6] Aliyu, I. \& Ibrahim, Z.F., Accidental carbon monoxide poisoning in a family of six: Diagnosis and treatment challenges in a resource limited setting. Journal of Medical Investigation and Practice, 9, 130-131, 2014.

[7] Nordqvist, C., Carbon monoxide (CO), the silent killer. Medical News Today, 11 November 2017.

[8] US EPA., Supplement to the Second Addendum (1986) to Air Quality Criteria for Particulate Matter and Sulfur Oxides (1982): Assessment of New Findings on Sulfur Dioxide and Acute Exposure Health Effects in Asthmatic Individuals. EPA/600/FP93/002, Washington, DC, 1994.

[9] ATSDR (Agency for Toxic Substances and Disease Registry), Toxicological Profile for Sulfur Dioxide. Atlanta, 1998. www.atsdr.cdc.gov/ToxProfiles/tp116.pdf.

[10] Health Effects Institute, State of global air 2018. Special report, Health Effect Institute: Boston, MA, 2018.

[11] Oyedele, E.A.A. \& Olayinka, A.I., Statistical evaluation of groundwater potential of Ado-Ekiti, South West Nigeria. Transnational Journal of Science \& Technology, 2(6), pp. 110-127, 2012.

[12] Awosusi, O.O. \& Jegede A.O., Challenges of sustainability and urban development: A case study of Ado-Ekiti, Ekiti State, Nigeria. International Education Research, 1(1), 22-29, 2013.

[13] Adebayo, W.O., Weather and climate. Ado-Ekiti region. A Geographical Analysis and Master Plan, ed. F.S. Ebisemiju, Alpha Prints: Lagos, pp. 11-14, 1993.

[14] US EPA (2014) AQI: A guide to air quality and your health. www3.epa.gov/airnow/aqi_brochure_02_14.pdf.

[15] US EPA (2016) Technical assistance document for the reporting of daily air quality the air quality index (AQI). www3.epa.gov/airnow/aqi-technical-assistancedocument-may2016.pdf. 